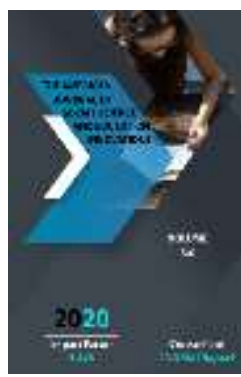

\title{
Representation Of Archeological Monuments Of Khorezm Oasis In Written Sources (6th Century Bc -10th Century Ad)
}

\section{Abdirimov R.}

Senior Researcher Of Khorezm Mamun Academy, Uzbekistan

Journal Website:

http://usajournalshub.c om/index,php/tajssei

\section{Copyright: Original} content from this work may be used under the terms of the creative commons attributes 4.0 licence.

\section{ABSTRACT}

The historical and cultural centers of the lower Amu Darya basin and its geologically connected Sarakamishbuyi and Uzboy areas and the economic activities of the population living in their micro districts in the ancient and medieval times can be described on the basis of scientific conclusions based on theoretical comparative analysis of written sources. The article considers the history of coverage of archeological monuments of Khorezm oasis in written sources.

\section{KEYWORDS}

Avesto, Var, Daxyu, Kavi, Yima, Hecate, Khorasmia, At-Tabari, Al-Muqaddasi, Al-Istahri, Kat, Gurganch, Amul, Marv.

\section{INTRODUCTION}

The construction of human settlements is recorded in Avesto, associated with the activities of Yima. The four-sided wall, erected by Yima, is described by the term "Square Vara". That is, he built the Yima Vara on all four sides, equal to horse's one run, and moved there the seeds of bulls, dogs, and birds, as well as the burning fire. The foursided horse-riding Varana was swept away by Yima, who brought water from a place a khatr (1.5 km) away. There he built enclosed dwellings on all sides, a house dome, and a courtyard. In the wide part of the building he built nine exits, six of which were medium and three narrow. And he opened the corridor and the lighted window".

However, although the term urban is not mentioned in the information recorded in the play, it is possible to have some idea of its archeological complex. The data recorded in Avesto indicate the beginning of a new historical period in the socio-economic 
relations of society. In the time of Avesto society, the historical and geographical boundaries of the pastoral and sedentary populations in the historical and cultural regions of the Central Asian region were defined. Military-political alliances had also been formed. The above-mentioned historical data found meaning and essence in the sense of "Square Vara". The "Square Vara" mentioned in Avesto is a fortress, which was developed by a special group of people, including the inner fortress, settlements, houses, handicraft workshops, streets, open spaces, defensive walls, the front and outskirts of the city, villages, fields. At the time of Avesto, there were historical and geographical regions such as Bactria, Sogdiana, Margiana, where the settlement of tribal associations was based on the system of irrigation.

Based on the knowledge of agriculture and handicrafts, the culture of urban planning has become an independent field. These regions are part of the Eastern urban planning system. As a product of the urban process, there was a process of formation on the basis of urban and city-states and on their basis the first state structures (Marokanda, Kyzyltepa, Koktepa, Yerkurgan, Uzunqir, Sangirtepa, Chirakchitepa). In Avesto, tribal communities and tribal relations are clearly described in the governing system of society. Issues such as defense, war, and truce were discussed in the tribal council, as well as conflicts over pastures and water with tribes living in the neighboring area. According to Avesto, in this historical period, the content of society was governed by the tribal association of the region - Dakhyu, the ruler of the association - "Kavi", the region - "Dakhyupati|". The chief of the tribe formed a tribal association by uniting a number of tribes in order to protect them from attack by neighboring cattle-breeding tribes and states. The chief of the tribal association, who had a large military force, invaded the neighboring territories, took possession of their property and enslaved the captives. As the position of tribal chief increased, he rose to the rank of chief of staff on the council as a result of the consolidation of personal power and served as military commander. His kin was considered great, and he himself became the sole ruler, and as his position in the community increased, he was able to form personal guards, ensuring the interests of his life and family, his accumulated wealth and security. Relying on personal guards, he subdued the tribes, organized military expeditions to neighboring territories, and gradually expanded the territory of the tribe, while maintaining its political and economic dominance. 


\section{Political terms mentioned in the book "Avesto"}

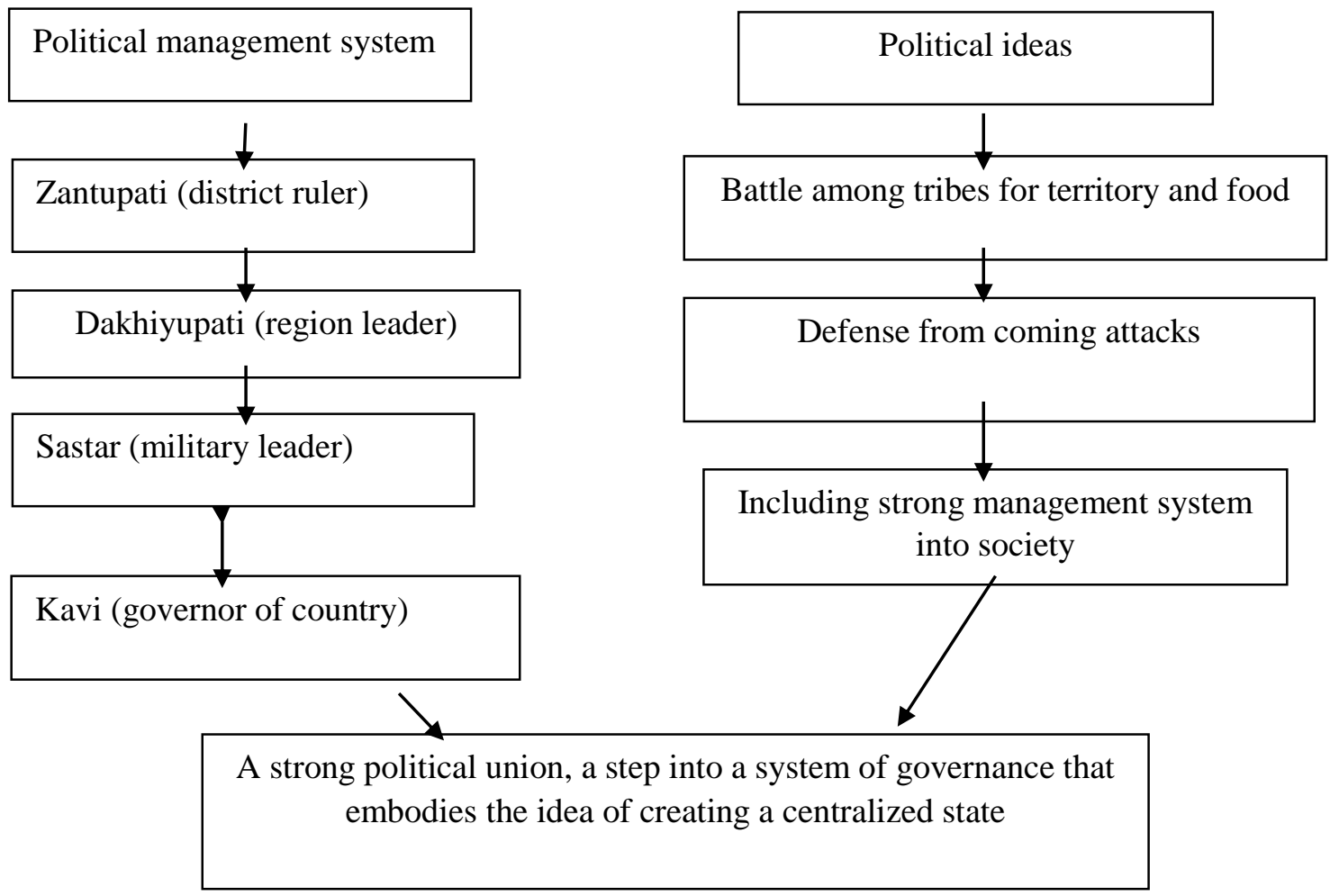

The data recorded in the works of GrecoRoman historians and Arab geographers have played an important role in covering the process of socio-economic and ethno-cultural relations in the ancient and medieval society of our country. Although real information about the history of Khorezm is reflected in Ahamanid cuneiform inscriptions (4th-5th centuries BC), Bihustun and Naqshi Rustam rocks, in artifacts from the fortresses of Suza, Hamodan and Personal, there is no information about the villages and towns built by the people of the oasis. The first historical information about the knowledge of our ancestors in the field of urban culture, which carried out economic activities in the oasis, can be traced in the work of the Greek historian Hecate Miletsky.

\section{MATERIALS AND METHODS}

In a special "Asia" section of Hecate Miletsky's work "Image of the Earth," he describes Asia, saying, "To the east of
Parthia, live Khorasmians who occupied the plains and mountains. In the mountains grow wild trees, willows, thorny cypress. At the beginning of the road passes through the land of the Parthians, a mountain, then the land of Khorasmians, in which there are mountains and plains. Here is their city "Khorasmia". Unfortunately, information about the topographic structure of the city and the defense complex is not reflected. The works of Arab tourists and geographers contain valuable information about the first and medieval villages and cities of Khorezm oasis. At-Tabarani's works contain information about the cities of Khazarasp Kat, Urgench. In the notes of a tourist who came to Khorez in the 7th century $A D$, information about the city of Kat is recorded. Al-Belozuri's work states that the area occupied by the Kat fortress is 200 hectares, equal to the size of the Afrasiab monument. An interesting legend about the history of Khorezm is presented in the work of the Arab 
geographer and traveler Al-Muqaddas. According to the legend, "The king of the East was angry with four hundred people for the services of his state. He ordered them to be taken to an uninhabited place a hundred miles away. They were brought to the place where the city of Kos is now located. Some time later, the king sent a man and ordered them to take notice of their condition. When the king's men come, all the exiles were alive; they built tents for themselves and made a living by fishing. They had a lot of firewood. When they had told those things to the king, he asked, "What do they say about meat?" Khor. And what about wood for fire? - Razm. Then the king said, "I have given those places to them". Let their land be called Khorezm. He then took four hundred Turkish girls and ordered them to be handed over to them.

Al-Muqaddas gives clear information that Khorezm oasis is surrounded by defensive walls and ditches of villages and towns. Khiva is surrounded by the majestic wall and ditch and on the sand border at the end of the irrigation structure. Zamakhshar is recorded as a small town, surrounded by a wall and a trench, in which a market with a square depicts a mosque at the end of it. The author pays special attention to the city of Kas, which is located on the eastern side of the Amu Darya. In it, the mosque is located in the middle of the market and the mosque is built of wooden pillars on a black stone that is the height of a man. The city is prosperous, rich in scientists, rich in food, rich in skilled architects and craftsmen. They recite wonderfully: their faces are also beautiful. That fact must be taken into account. "Not to mention the size of the layer, it equates its size and structure to Nishapur. Unfortunately, in the works of Arab geographers, there is not a single idea about the size of Kat.

At the same time, the tourist noted that the city of Darkhan is located on the trade route from Bukhara to Amul, Merv and Khorezm, around which there are about 500 vineyards.
The author notes that Gurganch has four gates, the interior of which is filled with residential buildings, surrounded by walls and ditches, the inhabitants are hospitable, love to eat, are not afraid of battle and are brave. He notes that they have unique and amazing features. Kas, Gartman, Oykhon, Ardakhiva, Nukfar, Kardar, Mizdahkon, Jashir, Sadvar, Zardukh, Barategin, Madkaminya, Jurjoniya, Nuzvor, Zamahshar, Ruzvand, (Ruzund), Daskahankhas, Khushmisan, Madamisan, Khiva, Kardaronkhos, Khazorasp (Khazorasf), Jigarband, Jazz, Dargan, Katta Jiz, Kichik Jiz, Kichik Jurjonia, Sadfar, Madkaminiya, Nuzvar, Darin, Juvinon, Amir, Barabsar, Vardara villages and towns. The work also contains information about the history of Khazorasp. In al-Muqaddas's works, Mizdahkon is a large city with 1,200 rustaks (arable villages). After Jurjonia, he left valuable information that Khorezm was a big city, where 500 vineyards stretched 2 miles along the river, and raisins were extracted. At the same time, the author mentions the fortress of Qalajik, west of Khazarasp.

Al-Istahri's work contains information about such rural settlements and cities as Khorezm (Kas, Kat), Dargan, Khazorasp, Khiva, Mizdahkon, Khushmisan, Ardakhushmisan, Safardiz, Nuzbar, Kardoronkhosh (Kardaronkhos), Andaraston Kurdar, Baratakin. The author writes about the city of Khorezm: "The capital of Khorezm is located north of Oks, the main city of the country is called Kat in Khorezm, but it was destroyed by Oks, and the people settled behind it. The river approached the castle again. There is also a possibility that the castle will collapse. The mosque is behind the castle. The palace of Khorezmshahs is next to this mosque. The dungeon is located near the castle, through which the Jardur Canal flows through the center of the city. It divides the city and the market into two parts. The width and length of the city is about $1 / 3$ of a mile. The gates in the ruined part of the city were destroyed. 
Khorezm is a rich city, rich in food. It is located on the west bank of the Oks River, a 3-day drive from Jurjonia. He noted that the circumference of the city of Kat was $2 \mathrm{~km}(1 / 2$ farsah), which had a rabod. Elsewhere in the work, he says, "Khorezm is a fertile city with a lot of food and fruits, but no nuts. Cotton is grown there and much more is made of it and these things are transported to distant places. The distinguishing feature of the population is the desire to show wealth and courage. They travel more than anyone. There is not a single city in Khurasan where the population does not live. There is no gold in their country, no silver mines, no mention of precious stones, and they often trade with the Turks. However, about Gurganch, "It is a place where Guzlar trades, where the caravan goes to Jurjania, Khazar and Khorasan". Hudud ul-Alam, written by an unknown author, lists 10 cities in the oasis. There is a lot of information about the cities of Gurganch and Kat. He noted that the city of Gurganch was divided into inner and outer parts, and that its inhabitants were well versed in the art of fighting and archery. The author writes: "Kat is the capital of Khorezm, the gateway to the Guzlar Turkestan, the city where the Turks, Turkestan, Movarounnahr and the Khazars gathered".

In the book "Kitab ul-Futuh" (Book of Conquests), the city of Khorezm is described as follows: Khorezm consists of three parts, which are surrounded by ditches. Al-Fir is the strongest part of the city. There is a large pool between the three parts of the city that provides them with water during the siege. Ibn Khurdodbek in his book "Kitab ul-masolik va al-mamolik" showed that along with Khorezm, the city Kat was surrounded by a wall and a ditch. Written sources and historical data first record the historical and political events that took place in the early medieval society of Khorezm oasis and the villages and towns that were surrounded by these events. Abu Rayhan Beruni studied the historical data recorded in Greek and Arabic sources, described the historical geography and geological structure of Khorezm, and in the agricultural oases, Khorezmians built more than 300 villages and towns on both banks of the river.

He noted that their ruins are still standing. At the same time, he noted the existence of a Siyavush-led state in Khorezm in the 5th century BC.

\section{RESULT AND DISCUSSION}

According to Abu Rayhan Beruni, the person who ruled the state with the title of Khorezmshah was Kaykhusrav, the son of Siyavush, the grandson of the king of Turan Afrosiyab. According to him, the Khorezmians got their history from the beginning of the settlement of people in Khorezm, which was nine hundred and eighty years before Alexander. Then they learned about the arrival of Siyavush ibn Kaykovus in Khorezm and the reign of Kaykhusrav and his descendants in Khorezm. At that time, Kaykhusrav moved to Khorezm and began the reign of the Turkish kings. This political process took place ninety-two years after the settlement of people in Khorezm. Then they followed the Iranians in making history, and each of the descendants of the so-called kings of Kaykhusrav (Khorezm) got a history (from the beginning of the tsarist period). Finally, the kingdom of Afrighiys began with the descendants of Kaykhisrav. Just as the Iranians sent the sinful Yazdijard to the evangelist (Khorezmians), they brought Afrigh to the evangelist. After Afrigh, his son became king. On the outskirts of the city of Alfir Khorezm was a fortress built of mud and mud bricks, built on three floors, located one inside the other and not far from each other in height. At the top of these forts were the palaces of kings.

Alfir was visible from a distance of ten miles or more. Every year Jaihun would tear it down, tear it down, and finally, in the one thousand three hundred and fifth year of 
Alexander's history, not a trace of it remained. Then Khorezmians took history from the kingdom of Afrighiys and its descendants, the representatives of the Afrighiys' dynasty Afrigh, Boza (Bughra), Sukhtang (Sahbang), Askajamuk, Azkojvor, Sukhoro, Shovush, Hamgari, Buzkor, Arsamukh (Artamux), Amurishi ozari and concluded that part of Khorezmians had moved to the shores of the Caspian Sea. During his trip to Khorezm, the Arab geographer Yakut said: "Khazorasp is like an island surrounded on four sides by water. A strong fortress enters the city from Khorezm side.

The population is engaged in trade, rich and wealthy", he said, noting that the Khazorasp people have a well-developed knowledge of clay architecture. Thus, based on the content of the historical data mentioned above, the following final conclusion can be drawn. The main productive force of the Lower Amu Darya, Sariqamishboyi and Uzbay, which formed a single territorial unit in terms of the borders of the oasis and naturally historicaleconomic and political-military, is the source of development of the ancient world society. At the same time, it can be explained that the content of economic activities in the historical and cultural massifs of the indigenous population, which is the creator of the development of society, is reflected in the toponymy of "khvarizam" and is an ancient ethnic group. The historical and cultural centers of the Lower Amu Darya Basin and its territorial continuation and its micro-districts are mentioned in the Achamanid sources under the term "Khvarazmish", managed by the rulers, allows them to obtain historical information about the tax policy levied on the population. Unfortunately, in this historical period, information related to the defense system of settlements built by the population in the territory of the oasis is not recorded. Because in the Avesto era, the knowledge of urban planning did not take place in the spirituality of the indigenous people. In the works of Greek historians, there is no information about the knowledge of Khorasmian clay architecture.

\section{CONCLUSION}

In the works of Arab geographers and tourists, large irrigation facilities built by the population on the right and left banks of the Amu Darya and agro-irrigated agricultural oases with a territorial boundary along the canal on both sides of them left clear information about their centers villages and cities. In the 16th century BC, villages and towns were centers of handicrafts and trade.

\section{REFERENCES}

1. Avesto. Vendidat. - Tashkent: Sharq, 2001. - P. 11, 33, 38.

2. Abaev V.I. The myth and history in the Ghats Zoroaster Historical and philological research) (Myth and history in the Ghats Zoroaster Historical and philological research II). - Moscow, Nauka, 1974 .-- P. 310-321.

3. Pyankov I.V. Khorasmiya of Hecate Miletskiy. M.VDI-2. Science 1972. - P. 8; Sulaymonova F. East and West. -Tashkent: Uzbekistan, 1997. - P. 12.

4. Mitt. T. 1, 1939. - P. 186-188. Al-belozuri. Arabian Sources of the 7 th-10th centuries. - Moscow-Leningrad: Science, 1960. - P. 2229. 